\title{
The morphological characters and DNA barcoding identification of sweet river prawn Macrobrachium esculentum (Thallwitz, 1891) from Rongkong watershed of South Sulawesi, Indonesia
}

\author{
JURNIATI $^{1,2, \vartheta}$, DIANA ARFIATI ${ }^{3}$, SAPTO ANDRIYONO ${ }^{4}$, ASUS MAIZAR SURYANTO HERTIKA ${ }^{3}$, \\ ANDI KURNIAWAN ${ }^{3}$, WENDY ALEXANDER TANOD ${ }^{5,6}$ \\ ${ }^{1}$ Graduate Program, Faculty of Fisheries and Marine Science, Universitas Brawijaya. J1. Veteran, Malang 65145, East Java, Indonesia. \\ Tel.: +62-341-553512, `email: unieqzul@gmail.com \\ ${ }^{2}$ Department of Aquaculture, Faculty of Fisheries, Universitas Andi Djemma. Jl. Sultan Hasanuddin No. 13, Palopo 91911, South Sulawesi, Indonesia \\ ${ }^{3}$ Department of Aquatic Resources Management, Faculty of Fisheries and Marine Science, Universitas Brawijaya. Jl. Veteran, Malang 65145, East Java, \\ Indonesia \\ ${ }^{4}$ Laboratorium Molecular Ecology, Department of Marine, Fisheries and Marine Faculty, Universitas Airlangga. Jl. Dr. Ir. H. Soekarno, Mulyorejo, \\ Surabaya 60115, East Java, Indonesia \\ ${ }^{5}$ Department of Fisheries and Marine Science, Politeknik Negeri Nusa Utara. Jl. Kesehatan, Mahena, Tahuna 95821, North Sulawesi, Indonesia \\ ${ }^{6}$ Sekolah Tinggi Perikanan dan Kelautan Palu. Jl. Soekarno Hatta, Tondo, Palu 94118, Central Sulawesi, Indonesia
}

Manuscript received: 27 August 2020. Revision accepted: 13 December 2020.

\begin{abstract}
Jurniati, Arfiati D, Andriyono S, Hertika AMS, Kurniawan A, Tanod WA. 2021. The morphological characters and DNA Barcoding identification of sweet river prawn Macrobrachium esculentum (Thallwitz, 1891) from Rongkong watershed of South Sulawesi, Indonesia. Biodiversitas 22: 113-121. Freshwater prawns of the genus Macrobrachium Bate, 1868 (Crustacea: Palaemonidae), play an essential role in freshwater ecosystems. Apart from being a crucial biotic component, freshwater prawns are also an important fishery commodity. The sweet river prawn Macrobrachium esculentum (Thallwitz, 1891) is a freshwater prawn that inhabits the Wallacea area and is a key constituent of crustacean biodiversity. However, morphological studies on Macrobrachium prawns that inhabit Sulawesi are still minimal. This study is the first report on the morphological and DNA barcoding identification of freshwater prawn M. esculentum downstream of the Rongkong watershed in South Sulawesi, Indonesia. The morphological characterization includes morphometric and meristic characteristics and is complemented by the DNA barcoding of the cytochrome c oxidase subunit I (COI) region. The analysis of the morphometric characteristics showed the formation of two population groups: the Waelawi River group and the Salujambu-Pombakka Rivers group. However, the meristic characteristics of M. esculentum from the three rivers were not significantly different. Meanwhile, the DNA barcoding analysis confirmed that the samples collected from the three rivers belong to the same species. This study provides information on the identification of $M$. esculentum inhabiting the Rongkong watershed and its population characters and grouping based on morphometric and meristic characteristics. This information can contribute to the management of fishery resources and the conservation of M. esculentum prawn resources in the Rongkong watershed, South Sulawesi, Indonesia.
\end{abstract}

Keywords: Endemic, freshwater, prawn, Wallacea, Sulawesi

\section{INTRODUCTION}

Freshwater prawns from the genus Macrobrachium Bate, 1868 (Crustacea: Palaemonidae), are a diverse group of decapod crustaceans. Their ancestors are marine prawn species, some of which eventually migrated to freshwater habitats, such as rivers, lakes, and peat swamps (Baeur 2013; Kounthongbang et al. 2015). Several studies have confirmed that these prawn inhabit a range of habitats, from seawater areas to freshwater habitats upstream (Anger 2013; Kuguru et al. 2019). Overall, there are at least 240 species of freshwater prawn (Short 2004) across tropical and subtropical areas (Sharma et al. 2014), but there are still many cryptic species that are not well described (Cai et al. 2004; Makombu et al. 2019). The genus Macrobrachium is divided into two major groups. One notable characteristic of the euryhaline group is its ability to adapt to a wide range of salinity (10-35 PSU). In contrast, the other group is only living in freshwater (Yatsuya et al. 2012).

In particular, M. esculentum is a freshwater prawn distributed throughout Taiwan, Sulawesi, Raja Ampat (Indonesia), and the Philippines, or the southern part of Asia (Roskov et al. 2014). Its size is relatively large. It is consumed locally, although it is not commercialized internationally. It is found in upstream of rivers with sand or mud substrate but also in downstream areas in brackish water. However, it has experienced a decrease in habitat area and quality due to anthropogenic land-use changes. Information about its morphological features and identification by DNA barcoding is not yet available (Pileggi and Mantelatto 2010; De Grave et al. 2011). Therefore, this study aims to provide some preliminary information about these aspects of $M$. esculentum in the downstream rivers of the Rongkong watershed, South Sulawesi, Indonesia. 
Given the diversity of species in this genus, identification by morphology alone can sometimes lead to errors. Thus, identification was also carried out using a DNA barcoding approach. In Java and Bali, Indonesia, molecular identification of the genera Macrobrachium and Caridina has been successfully carried out with a target region of mitochondrial DNA, namely the cytochrome c oxidase subunit I (COI). COI has been commonly used in the molecular identification of other prawns and is an agreed-upon region for barcoding (Hebert et al. 2003a,b; Udayasuriyan et al. 2015; Subbaiya et al. 2017). Studies on the freshwater prawn genus Macrobrachium have been carried out in other areas such as in Kalimantan, Sumatra, and Papua (Imron et al. 2009). Information on Macrobrachium in South Sulawesi is still minimal (Nugroho et al. 2009), although a few studies have examined Macrobrachium species in South Sulawesi, namely M. horstii from a river near Palopo (Wowor and Choy 2001); M. esculentum from the Pongkeru River (Wowor et al. 2009); and $M$. rosenbergii and $M$. idae from Lake Tempe, North Luwu, and the Kariango and Kalibone Rivers (Wahidah et al. 2015, 2017). Another study determined the length-weight relationships and condition factor of $M$. esculentum (Jurniati et al. 2019). However, the morphological and DNA barcoding identification of $M$. esculentum in the downstream Rongkong watershed has not been performed.

Therefore, the present study aimed to identify the morphological features and DNA barcoding identification of the sweet river prawn Macrobrachium esculentum (Thallwitz, 1891) from the Rongkong watershed in South Sulawesi, Indonesia. Notably, Nugroho et al. (2008) concluded that the genetic diversity of giant freshwater prawns from South Sulawesi, Indonesia, was significantly different from those in Kalimantan, West Java, and Sumatra (also in Indonesia). This evidence reinforces the claim that the Wallacea region has a high level of endemism (Michaux 2010; Stelbrink et al. 2012). Specifically, the morphometric and meristic characteristics of Macrobrachium esculentum collected from the Rongkong watershed, South Sulawesi, Indonesia, were analyzed. Then, its identification was confirmed by the DNA barcoding of the COI region, and its phylogenetic tree was also reconstructed to analyze its relationship to its closest relatives based on sequences from the GenBank database. This is the first report on the morphological and DNA barcoding identification of the freshwater prawn $M$. esculentum downstream of the Rongkong watershed, South Sulawesi, Indonesia.

\section{MATERIALS AND METHODS}

\section{Collection of materials}

Freshwater prawn samples were collected from the downstream part of the Rongkong watershed once a month from September 2018-August 2019. The coordinates of the sampling stations are presented in Table 1. The stations were located along the banks of three rivers used by traditional fishermen as fishing grounds for Macrobrachium prawns: the Waelawi, Salujambu, and Pombakka Rivers.
These sites are marked by the presence of traditional fishing traps made of bamboo (local name: kopa). Three sampling stations were selected at each river (Figure 1). Samples were obtained using kopa according to a simple random sampling method in which each member of the population has the same probability of being selected (Thompson 2012; Laewa et al. 2018). The number of M. esculentum individuals obtained from the Waelawi River was 54 (34 males, 20 females), from the Salujambu River was 53 (33 males, 20 females), and from the Pombakka River was 54 (34 males, 20 females). Initial morphological identification was carried out following Chace and Bruce (1993) and Wowor and $\mathrm{Ng}$ (2004) at the Basic Laboratory of the Agrokompleks, Andi Djemma University, Palopo, South Sulawesi. To corroborate the morphological classification, identification was carried out simultaneously by the Indonesian Institute of Sciences (LIPI) Laboratory Biology Center, Cibinong Bogor, Indonesia. The samples were stored in alcohol (96\%) at the Museum Zoologicum Bogoriense under specimen code MZB Cru 5149. Molecular identification was carried out at the Indonesian Biodiversity Laboratory, Denpasar, Bali; samples were sent to PT. Genetika Science, Jakarta, Indonesia.

\section{Morphological characterization}

Morphological measurements were based on identification manuals outlined in previous studies (Short 2004; Adite et al. 2013). These included nine morphometric and two meristic characters (Table 2). The measurement of the morphometric characters was based on Munasinghe and Thushari (2010). Digital calipers with an accuracy of 0.01 $\mathrm{mm}$ were used. Sex observations were made based on visual morphological differences documented in previous research (Cuvin-Aralar 2014).

The morphometric and meristic measurement data from the three rivers were compared using discriminant function analysis with clusters previously tested by the KaiserMeyer-Olkin (KMO) test, with criteria ranging from 0.5 to 1. The KMO test was performed in the software SPSS statistics version 17 (Bryman and Cramer 2011). The analysis of each rivers meristic characters was based on the percentage distribution of upper and lower rostrum serrations in male and female M. esculentum. A covariance analysis was carried out to determine whether there are differences between the three rivers.

\section{Identification with DNA barcoding}

The identity of the freshwater prawn samples confirmed morphologically as M. esculentum was further corroborated using the DNA barcoding method. The abdominal meat of the prawn samples was used for DNA extraction. The Qiagen DNeasy Blood and Tissue Kit (Germany) was used according to the manufacturer's protocol. The genomic DNA was then reproduced by the PCR technique in the gene region Cytochrome c oxidase subunit I (COI) using the primers jgLCO1490 and jgHCO2198 (Geller et al. 2013). Each reaction consisted of a mixture of $4 \mu \mathrm{L}$ of $10 \mathrm{x}$ PCR buffer (Applied Biosystems), $2.5 \mu \mathrm{L}$ of $10 \mathrm{mM}$ dNTPs, $1.2 \mu \mathrm{L}$ of $10 \mathrm{mM}$ of each primer, $2 \mu \mathrm{L}$ of $25 \mathrm{mM} \mathrm{MgCl}_{2}$, 0.125 of $\mu \mathrm{L}$ AmplyTaq GoldTM (Applied Biosystems), and $14.5 \mu \mathrm{L}$ of $\mathrm{ddH}_{2} \mathrm{O}$. 

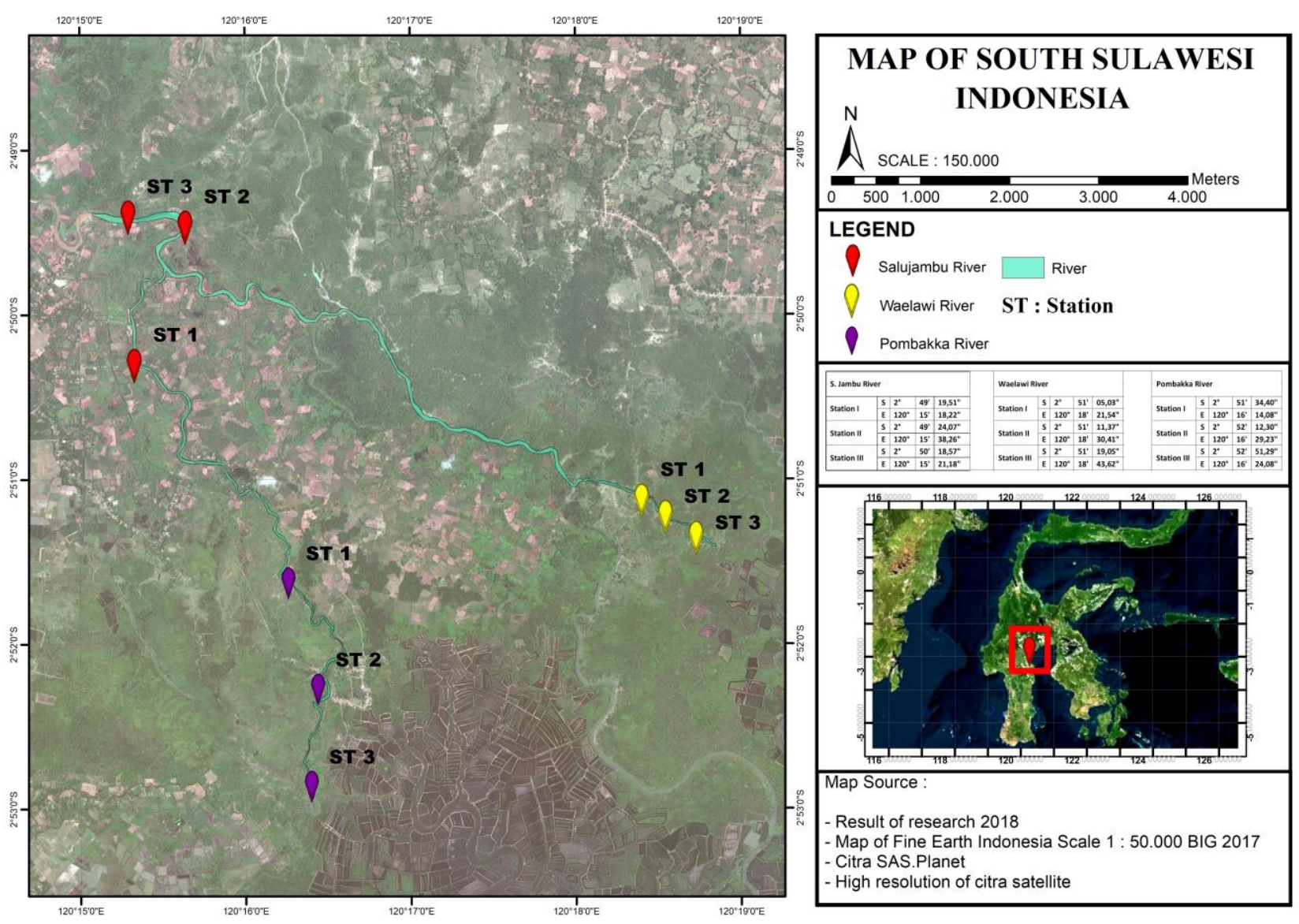

Figure 1. Sampling site distribution of Macrobrachium esculentum at downstream of Rongkong Watershed, South Sulawesi, Indonesia

Table 1. Coordinate sampling locations

\begin{tabular}{lccc}
\hline Sampling location & Station 1 & Station 2 & Station 3 \\
\hline Waelawi & $-2.851 \mathrm{~S}$ and 120.305 E & $-2.853 \mathrm{~S}$ and 120.308 E & $-2.855 \mathrm{~S}$ and 120.312 E \\
Salujambu & $-2.822 \mathrm{~S}$ and 120.255 E & $-2.823 \mathrm{~S}$ and 120.260 E & $-2.838 \mathrm{~S}$ and 120.255 E \\
Pombakka & $-2.859 \mathrm{~S}$ and 120.270 E & $-2.870 \mathrm{~S}$ and 120.274 E & $-2.880 \mathrm{~S}$ and 120.273 E \\
\hline
\end{tabular}

Table 2. Characteristics, symbol, and definition of morphological and meristic characters measures for Macrobrachium esculentum

\begin{tabular}{|c|c|c|}
\hline Characteristics & Symbol & Definition of characteristics \\
\hline \multicolumn{3}{|l|}{ Morphometric characters } \\
\hline Total length & TL & Length from antennule to telson end \\
\hline Abdominal Length & $\mathrm{AL}$ & Length from front carapace to the tip of telson \\
\hline Telson Length & Tel & The maximum length of the telson \\
\hline Carapace Length & CL & Length from the base of the eye to the border of the front carapace \\
\hline Carapace width & $\mathrm{Cw}$ & Maximum carapace width \\
\hline Carapace diagonal length & $\mathrm{CdL}$ & The length of the base of the eye to the limit of the lower carapace \\
\hline Length of the first abdominal & LA1 & Maximum length in the first abdominal segment \\
\hline Rostrum length & RL & Length from tip to the base of rostrum \\
\hline Length of the second abdominal & LA2 & The maximum length in the second abdominal segment \\
\hline \multicolumn{3}{|l|}{ Meristic characters } \\
\hline Number of upper teeth of rostrum & NUT & The total number of teeth at the upper of the rostrum \\
\hline Number of lower teeth of rostrum & NLT & The total number of lower teeth at the rostrum \\
\hline
\end{tabular}


The total volume in the PCR process was $25 \mu \mathrm{L}$, with 1 $\mu \mathrm{L}$ corresponding with the DNA concentration. Meanwhile, the PCR conditions were as follows: pre-denaturation at $94^{\circ} \mathrm{C}$ for 14 seconds, denaturation at $94^{\circ} \mathrm{C}$ for 30 seconds, annealing at $50^{\circ} \mathrm{C}$ for 30 seconds, and extension at $72^{\circ} \mathrm{C}$ for 45 seconds. The denaturation to extension was carried out for 38 cycles and ended with a final extension process at $72^{\circ} \mathrm{C}$ for 5 minutes. The PCR results were monitored using $1 \%$ agarose gel mixed with DNA dye from Biotium. The PCR products that were successfully amplified were sent for sequencing at PT. Genetika Science Indonesia, Jakarta. The results of the sequence (forward and reverse) were edited using Chromas (http://technelysium.com.au/wp/chromas/) and further processed using the MEGA 7 program (Kumar et al. 2016). The obtained sequences were also compared with the sequences of the same species in the NCBI GenBank database to observe their similarity (\% identity and $\%$ query cover).

\section{Data analysis}

Morphological data were analyzed in Microsoft Excel 2013 and SPSS 17 (Bryman and Cramer 2011). The mean, range, and standard deviation $( \pm \mathrm{SD})$ of each feature were calculated for each river. The values were calculated for both sexes combined. The data were analyzed using a covariance analysis including the nine morphometric characters. The carapace length (CL) was analyzed as the independent variable and the eight other morphometric characters as the dependent variables (Table 2). Meristic characters were measured by counting the number of upper and lower rostrum spines in the samples; these were compared among the three rivers and the literature. The molecular sequences were aligned and processed using the Mega 7 Software (Kumar et al. 2016) to produce phylogenetic trees and calculate genetic distance. Phylogenetic tree analysis was performed using the neighbors-joining model with 1000 bootstrap replications.

\section{RESULTS AND DISCUSSION}

\section{Identification}

The freshwater prawn samples found in the downstream Rongkong watershed were medium to adult size, blackish gray in color, and striated along the abdomen. They have a short rostrum that does not reach the antenna and curves downward, with 11-14 upper rostrum teeth and 2-4 lower rostrum teeth. Their total length ranges from 3.66-8.99 cm. The initial morphological examination identified the sample as Macrobrachium esculentum (Thallwitz, 1891). To corroborate this identification, we sent the samples to be identified by the crustacean expert Dr. Daisy Wowor from the Crustacean Laboratory, Center for Biological Research, Indonesian Institute of Sciences. Then, the identity was further corroborated by DNA barcoding. This is the first report on $M$. esculentum in the downstream Rongkong watershed, South Sulawesi, Indonesia. Samples of $M$. esculentum are shown in Figure 2.

The PCR amplification showing 700-bp amplicons was carried out using DNA barcoding. The DNA barcoding results were searched in BLASTN in the GenBank database, finding $99.41 \%$ similarity with $M$. esculentum from the Sulawesi region (FM958064). The morphological and DNA barcoding identification confirmed that the samples from the three rivers were the same species. This finding confirms previous research that $M$. esculentum has a habitat in the Rongkong watershed, South Sulawesi. The phylogenetic tree (Figure 3) was constructed with several species belonging to the same clade. It shows little genetic variation between $M$. esculentum samples from the Rongkong watershed and the Pongkeru River in South Sulawesi (Wowor et al. 2009) and that M. esculentum is closely related to $M$. nipponense (86\%), which inhabits Asia's freshwaters (Cui et al. 2018).

Until now, $M$. esculentum has only been recorded in Indonesia, the Philippines, and Chinese Taipei. The Global Biodiversity Information Facility (GBIF) has records of $M$. esculentum from the Mimanga River, Minahasa, North Sulawesi, Indonesia (Senckenberg 2004); Pongkeru River, South Sulawesi, Indonesia (The International Barcode of Life Consortium 2016); Tempe Lake, South Sulawesi, Indonesia (Goud et al. 2020); Philippines (Akiba and Sasaki 2020); and Chinese Taipei (De Grave 2017). The diversity of the Macrobranchium genus in the Wallacea region is significant, which might be expected in the South Sulawesi region considering its diverse geographical and riverine conditions. On the IUCN Red List, it is noted that M. esculentum is a fully migratory freshwater prawn that inhabits the downstream part of rivers with a sand/mud substrate not far from the sea at the confluence of freshwater and brackish water (De Grave et al. 2013). The downstream geomorphological structure of the Rongkong watershed corresponds with that of a wetland and estuary area (Hijiriah 2015), providing suitable habitat for $M$. esculentum. The habitat type of $M$. esculentum is wetlands (inland), and it is listed as not threatened (of least concern) according to the IUCN (De Grave et al. 2013). Historically, there have been challenges in documenting genetic information for marine resources in Indonesia, a megabiodiverse country. Thus, the present study makes a contribution toward this effort (Muthmainnah et al. 2016).

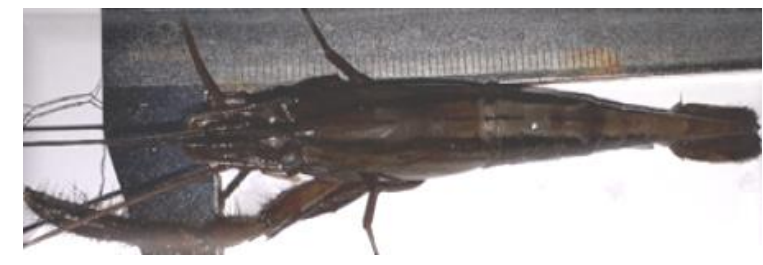

Figure 2. Macrobrachium esculentum collected from downstream of Rongkong Watershed, South Sulawesi, Indonesia 


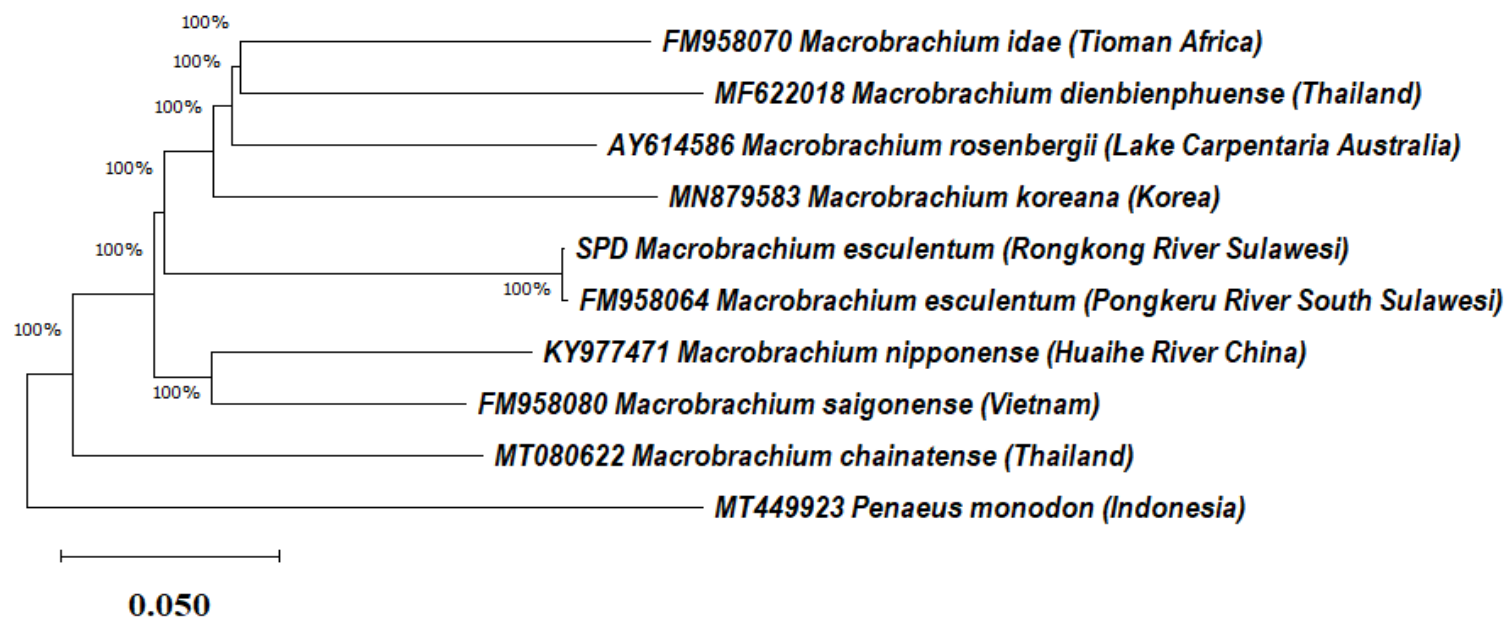

Figure 3. Phylogenetic tree of Macrobrachium esculentum from downstream of Rongkong watershed at South Sulawesi, Indonesia

\section{Morphometric and meristic characteristics}

The morphometric and meristic characters of the male and female populations were also measured separately. In the Waelawi River, M. esculentum has a shorter carapace length (CL). In the Pombakka River, males and females have almost the same carapace length, although female prawn has a shorter total length of $5.99 \pm 1.25$ (Table 2). The Pombakka River is closer to the Rongkong watershed's mouth, so the prawn in this river is likely more ready to spawn (also indicated by the increase in egg diameter and level of gonad maturity), affecting the length of the carapace. This reflects the life cycle of prawns (especially the genus Macrobrachium) who migrate to the sea as they reach the adult stage to spawn (Bauer 2013).

Table 2 showed the morphometric characters of $M$. esculentum from the Waelawi, Salujambu, and Pombakka Rivers had a range of coefficient of variation (CV) of 8.03$65.69 \%$. The lowest CV (8.03\%) was found for female rostrum length in the Waelawi River. The highest CV was found for female second abdominal length $(51.24 \%)$ in the Pombakka River. The mean $\mathrm{CV}$ values of the morphometric variables for the female population in the Waelawi, Salujambu, and Pombakka Rivers were $12.95 \%$, $32.71 \%$, and $27.95 \%$, respectively, and for the male prawn, population was $21.36 \%, 24.20 \%$, and $22.71 \%$, respectively. The female population of $M$. esculentum was more heterogeneous than the male population, and the morphometric characters of the second abdomen length (LA2) were more varied than the eight other morphometric characters. These findings are presumably related to the characteristics of the ovigerous females: The second abdomen (LA2) length varies according to the stage of embryo development of incubated eggs (Bauer 2011; Omobepade and Ajibare 2015; Ventura et al. 2019).

The principal component analysis (PCA) in Figure 4 showed the relationship of the nine morphometric characters of six populations of M. esculentum (male and female populations of Waelawi, Salujambu, and Pombakka Rivers). Two groups were formed: Component 1 (blue circle) is a population grouped according to the length of the rostrum (RL) and length of the second abdomen (LA2), including $15.96 \%$ of the samples. In contrast, component 2 (yellow circle) is a population grouped according to similarities in first abdominal length (LA1), telson length (Tel), abdominal length (AL), carapace length (CL), carapace diagonal length $(\mathrm{CdL})$, and carapace width $(\mathrm{Cw})$, including $60.59 \%$ of the samples.

Table 2. Morphometric and meristic parameters of Macrobrachium esculentum from three rivers

\begin{tabular}{|c|c|c|c|c|c|c|}
\hline \multirow{3}{*}{$\begin{array}{l}\text { Morphometric } \\
\text { and meristic } \\
\text { parameters }\end{array}$} & \multicolumn{6}{|c|}{ Sampling Site } \\
\hline & \multicolumn{2}{|c|}{ Waelawi } & \multicolumn{2}{|c|}{ Pombakka } & \multicolumn{2}{|c|}{ Salujambu } \\
\hline & Male & Female & Male & Female & Male & Female \\
\hline TW & $1.83 \pm 0.74$ & $2.02 \pm 0.61$ & $3.91 \pm 1.67$ & $4.40 \pm 2.43$ & $6.30 \pm 3.80$ & $4.89 \pm 3.37$ \\
\hline TL & $4.64 \pm 068$ & $4.85 \pm 0.52$ & $5.73 \pm 0.62$ & $5.99 \pm 1.25$ & $6.47 \pm 1.23$ & $5.82 \pm 1.43$ \\
\hline $\mathrm{AL}$ & $2.47 \pm 0.43$ & $2.61 \pm 0.28$ & $3.04 \pm 0.36$ & $3.11 \pm 0.65$ & $3.35 \pm 0.65$ & $3.08 \pm 0.73$ \\
\hline Tel & $0.68 \pm 0.19$ & $0.65 \pm 0.07$ & $0.84 \pm 0.28$ & $0.86 \pm 0.13$ & $0.84 \pm 0.13$ & $0.81 \pm 0.22$ \\
\hline CL & $1.39 \pm 0.21$ & $1.35 \pm 0.18$ & $1.86 \pm 0.26$ & $1.80 \pm 0.51$ & $1.85 \pm 0.54$ & $1.75 \pm 0.60$ \\
\hline $\mathrm{Cw}$ & $0.88 \pm 0.14$ & $0.91 \pm 0.12$ & $1.20 \pm 0.30$ & $1.18 \pm 0.28$ & $1.22 \pm 0.26$ & $1.12 \pm 0.37$ \\
\hline $\mathrm{CdL}$ & $1.52 \pm 0.26$ & $1.50 \pm 0.15$ & $2.09 \pm 0.33$ & $2.03 \pm 0.49$ & $2.17 \pm 0.43$ & $1.91 \pm 0.61$ \\
\hline LA1 & $0.26 \pm 0.14$ & $0.22 \pm 0.03$ & $0.31 \pm 0.07$ & $0.35 \pm 0.06$ & $0.33 \pm 0.12$ & $0.33 \pm 0.11$ \\
\hline LA2 & $0.49 \pm 0.09$ & $0.54 \pm 0.07$ & $0.52 \pm 0.09$ & $0.78 \pm 0.40$ & $0.61 \pm 0.17$ & $0.56 \pm 0.15$ \\
\hline RL & $1.31 \pm 0.19$ & $1.29 \pm 0.10$ & $1.64 \pm 0.23$ & $1.62 \pm 0.36$ & $1.65 \pm 0.33$ & $1.64 \pm 0.46$ \\
\hline NUT & $12.62 \pm 0.95$ & $12.70 \pm 0.73$ & $13.26 \pm 0.86$ & $12.95 \pm 1.23$ & $13.70 \pm 1.83$ & $13.10 \pm 0.72$ \\
\hline NLT & $2.32 \pm 0.53$ & $2.25 \pm 0.55$ & $2.50 \pm 0.66$ & $2.60 \pm 0.68$ & $2.94 \pm 0.79$ & $2.30 \pm 0.57$ \\
\hline
\end{tabular}




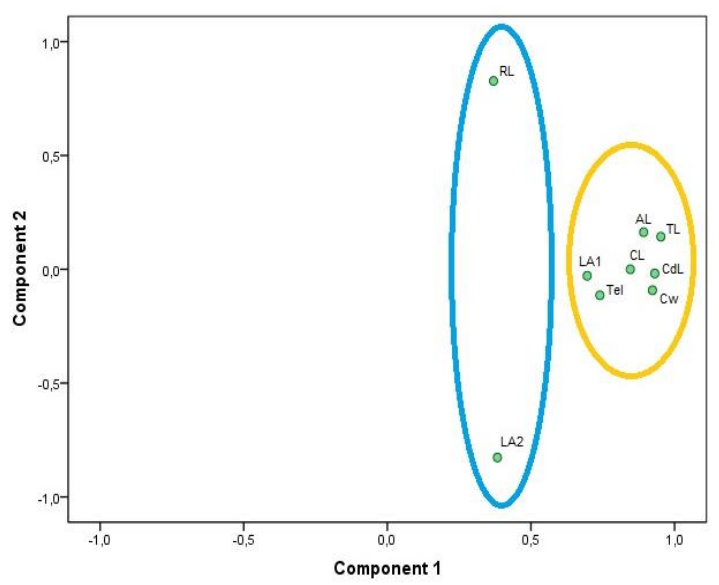

Figure 4. Morphometric parameter component diagram based on Principal Component Analysis (PCA). TL: Total length; AL: Abdominal length; Tel: Telson; CL: Carapace length; $\mathrm{Cw}$ : Carapace width; CdL: Carapace diagonal length; RL: Rostrum length; LA1: Length of the first abdominal; LA2: Length of the second abdominal.

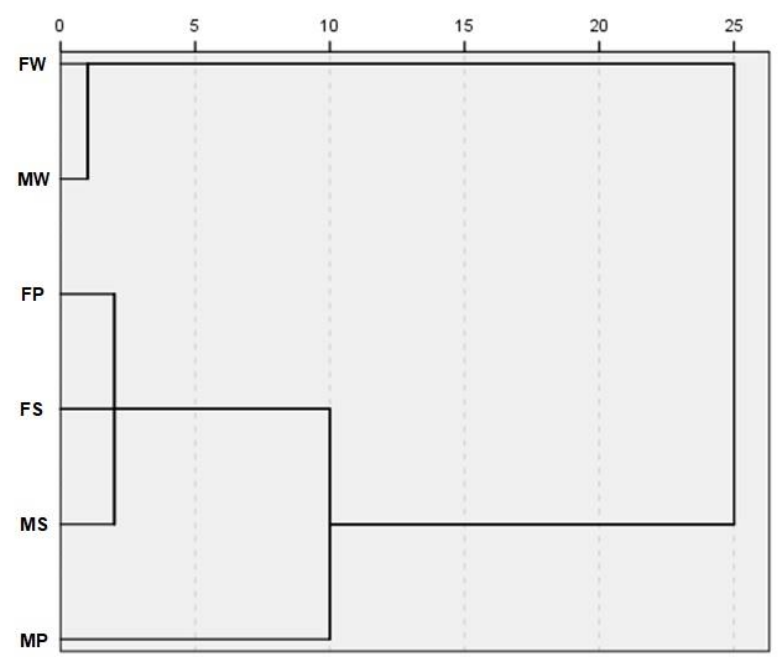

Figure 5. Dendrogram clusters of male and female Macrobrachium esculentum populations inhabiting from the Waelawi, Salujambu, and Pombakka rivers of the Rongkong watershed. FW: Female Waelawi; MW: Male Waelawi; FP: Female Pombakka; MP: Male Pombakka; FS: Female Salujambu; MS: Male Salujambu.

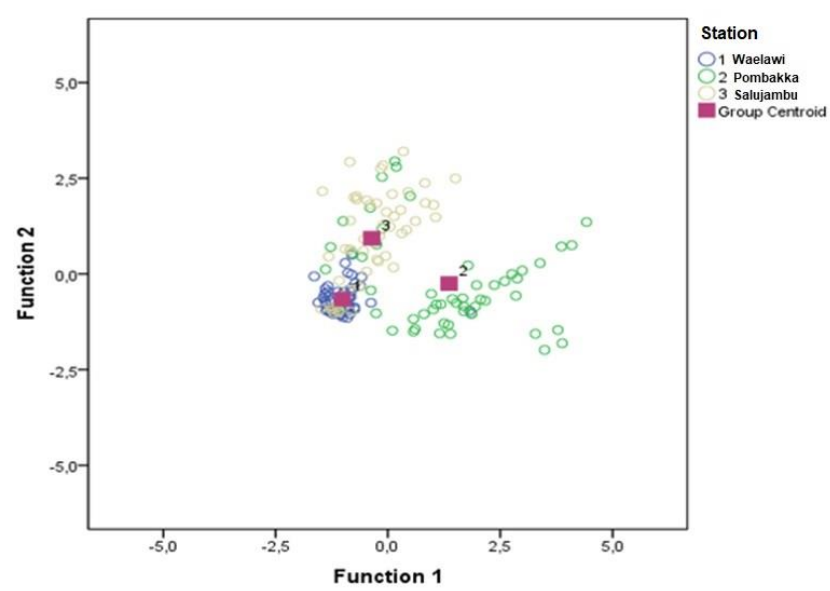

Figure 6. Discriminant function plot cluster on Macrobrachium esculentum populations from the Waelawi, Salujambu, and Pombakka rivers in Rongkong Watershed, South Sulawesi, Indonesia

The cluster analysis in Figure 5 showed two population groups (male and female) with similarities based on the observed characters. The first group consists of male and female M. esculentum from Sungai Waelawi; these separate form clusters presumably because the Waelawi River flows from the upstream part of the Rongkong watershed. The second group consists of male and female prawn populations from the Salujambu and Pombakka Rivers, which flow from the Rongkong and Lamasi watersheds.

The morphometric characters of $M$. esculentum were additionally analyzed by discriminant function analysis to obtain a centroid graph depicting the separation of each population. Figure 6 showed that the populations of the three rivers are significantly different $(\mathrm{p}>0.05)$. This analysis suggests that the populations of $M$. esculentum in the downstream Rongkong watershed can be differentiated based on morphometric characteristics.

The spines on the rostrum section are commonly used to assess the meristic characteristics of Macrobrachium species and are the main taxonomic characteristics used to identify freshwater prawn species (Wowor and $\mathrm{Ng} \mathrm{2007}$; Adite et al. 2013; Chen et al. 2015; Kaka et al. 2019). The number of serrations under the rostrum (ventral) in almost all male and female specimens was the same. However, the number of serrations above the rostrum (dorsal) was more diverse (Table 3).

Table 3. Range number of serrations between dorsal and ventral position

\begin{tabular}{lcccc}
\hline \multirow{2}{*}{ River name } & \multicolumn{2}{c}{ Number of serrations above rostrum (dorsal) } & Number of serrations under rostrum (ventral) \\
\cline { 2 - 5 } & Male & Female & Male & Female \\
\hline Waelawi & $11-14$ & $11-14$ & $2-4$ & $2-4$ \\
Salujambu & $12-14$ & $11-15$ & $2-4$ & $2-4$ \\
Pombakka & $12-14$ & $12-15$ & $2-4$ & $2-4$ \\
\hline
\end{tabular}


The morphometric approach enables the comparison and distinction of individuals, populations, and communities. The characters analyzed herein were previously determined for the species of the family Palaemonidae (Jayachandran and Sebastian 2010; Munasinghe and Thushari 2010; Fadli et al. 2018; Kumar et al. 2018). Morphometric and meristic characters can be the basis for further population structure research, wherein environmental factors can be considered among the causes of differences in these characters (Adite et al. 2013; Ahmadi 2018).

The year-long sampling (September 2018-August 2019) obtained a sufficient number of samples in September 2018 (75 individuals) and January 2019 (86 individuals). However, the samples in December 2018 and in February, March, April, May, and June 2019 were too low ( $<10$ ), and in October and November 2018 and July and August 2019 , no individuals were found. It can be assumed that the sampling points (Waelawi, Salujambu, and Pombakka Rivers) are not the sole habitat of $M$. esculentum because it was found only in certain months, namely when it entered the estuary to spawn, which was reflected by the dominant ovigerous female sample. The IUCN Red List notes that $M$. esculentum is a freshwater prawn with a fully migratory pattern in native wetlands habitats wholly or partially submerged in water with calm water conditions. However, in this study, the fishing traps were installed along the Salujambu, Pombakka, and Waelawi Rivers with a reasonably heavy flow, so it is assumed that much of the M. esculentum samples caught by these traps were females ready to migrate and spawn in the estuary area. The Global Biodiversity Information Facility (GBIF) also reported the presence of M. esculentum in January, July, August, and November.

In the literature, $M$. rosenbergii in the Lempuing River, South Sumatra, Indonesia, was reported to migrate to the estuary to spawn in December-February (Utomo 2017). Macrobrachium ohione in the Mississippi River was reported to migrate to the estuary to spawn in March-June (Bauer and Delahoussaye 2008; Olivier and Bauer 2011). The population of $M$. esculentum analyzed herein was found in relatively small numbers and is therefore thought to have decreased in population due to reduced habitat area and quality. In the sampling results, it is suspected that one of the factors in nature that causes the number of $M$. esculentum to decrease is a higher population of male versus female prawns. As long ago as 1956, this species was listed as one of the most commercialized species in the Philippines, yet recently, it is found in relatively small numbers in local markets, possibly confirming its decline.

This study provides information about the morphometric and meristic characteristics of $M$. esculentum sampled in three rivers (Waelawi, Salujambu, and Pombakka) in the downstream part of the Rongkong watershed. Based on the measured morphometric characters, two groups were formed. The meristic characters differed among the samples from the Waelawi, Salujambu, and Pombakka Rivers, although not significantly. The morphological diversity indicates phenotypic plasticity in these populations, or the ability to generate morphological alternatives to changing environmental conditions (Fusco and Minelli 2010). Morphometric variations in geographic populations can be caused by genetic and ecological conditions (Bauer 2011; Mar et al. 2018).

The management of $M$. esculentum in South Sulawesi still requires further research on its reproductive parameters. However, these results can be useful for fisheries for the management and conservation efforts of the sweet river prawn $M$. esculentum inhabiting the downstream part of the Rongkong watershed (particularly the Waelawi, Salujambu, and Pombakka Rivers). In addition, these data enable a comparison of the morphological features of $M$. esculentum with the Macrobrachium from other rivers in Indonesia.

\section{ACKNOWLEDGEMENTS}

We want to acknowledge the Indonesian Endowment Fund for Education (LPDP-BUDI DN), the Ministry of Finance, and the Ministry of Education and Culture, the Republic of Indonesia, which provides scholarships to the first author, a grant No. PRJ-354/LPDP.4/2019. We also thank Dr. Daisy Wowor and Adi Wijaya, for their support in identification and analysis. Hopefully, this article is useful and contributes to the management and conservation of M. esculentum in South Sulawesi, Indonesia.

\section{REFERENCES}

Adite A, Abou Y, Sossoukpe E, Gbaguidi MG, Fiogbe ED. 2013. Meristic and morphological characterization of the freshwater prawn, Macrobrachium macrobrachion (Herklots, 1851) from the mono river coastal lagoon system, southern Benin (West Africa): implications for species conservation. Intl J Biodivers Conserv 5: 704-714.

Ahmadi A. 2018. Morphometric characteristic of Macrobrachium sp. from Barito River, Indonesia. Intl J Innov Stud Aquat Biol Fish 4: 1931 .

Akiba M, Sasaki T. 2020. Crustacea specimens of Ryukyu University Museum (Fujukan). Version 1.2. National Museum of Nature and Science, Japan. Occurrence dataset DOI: 10.15468/vdwqzo accessed via GBIF.org on 2020-11-19. https://www.gbif.org/occurrence/1830788715

Anger K. 2013. Neotropical Macrobrachium (Caridea: Palaemonidae): on the biology, origin, and radiation of freshwater-invading shrimp. $\mathbf{J}$ Crustacean Biol 33: 151-183.

Bauer RT, Delahoussaye J. 2008. Life history migrations of the amphidromous river shrimp Macrobrachium ohione from a continental large river system. J Crust Biol 28: 622-632.

Bauer RT. 2011. Amphidromy and migrations of freshwater shrimps. I. Costs, benefits, evolutionary origins, and an unusual case of amphidromy. In: Asakura A (eds.). New Frontiers in Crustacean Biology. Koninklijke Brill NV, Leiden.

Bauer RT. 2013. Amphidromy in shrimps: a life cycle between rivers and the sea. Lat Am J Aquat Res 41: 633-650.

Bryman A, Cramer D. 2011. Quantitative data analysis with IBM SPSS 17, 18 and 19. Routledge, New York.

Cai Y, Naiyanetr P, Ng, PKL. 2004. The freshwater prawns of the genus Macrobrachium Bate, 1868, of Thailand (Crustacea: Decapoda: Palaemonidae). J Nat Hist 38: 581-649.

Chace FA, Bruce AJ. 1993. The caridian shrimps (Crustacea: Decapoda) of the Albatross Philippine Expedition, 1907-1910, Part 6: Superfamily Palaemonoidea. Smithsonian Contrib Zool 543: 1-152. 
Chen PC, Tzeng TD, Shih CH, Chu TJ, Lee YC. 2015. Morphometric variation of the oriental river prawn (Macrobrachium nipponense) in Taiwan. Limnologica 52: 51-58.

Cui F, Yu Y, Bao F, Wang S, Xiao MS. 2018. Genetic diversity analysis of the oriental river prawn (Macrobrachium nipponense) in Huaihe River. Mitochondrial DNA A 29: 737-744.

Cuvin-Aralar MLA. 2014. Embryonic development of the caridean prawn Macrobrachium mammillodactylus (Crustacea: Decapoda: Palaemonidae). Invertebr Reprod Dev 58: 306-313.

De Grave S, Fransen CHJM. 2011. Carideorum Catalogus: The recent species of the Dendrobranchiate, Stenopodidean, Procarididean and Caridean shrimps (Crustacea : Decapoda). Zool Meded 85: 195-588.

De Grave S, Wowor D, Shy J. 2013. Macrobrachium esculentum. The IUCN Red List of Threatened Species 2013: e.T198185A2515154 DOI: $\quad$ 10.2305/IUCN.UK.2013-1.RLTS.T198185A2515154.en. Downloaded on 19 November 2020.

De Grave S. 2017. Global caridean shrimp fauna. Version 2.3. BioFresh. Occurrence dataset DOI: $10.13148 / \mathrm{bfcf} 7$ accessed via GBIF.org on 2020-11-19. https://www.gbif.org/occurrence/1262422670

Fadli A, Binur R, Kawulur EIJJ. 2018. Morphology variation of Macrobrachium lar (Fabricius, 1798) occurring in Rivers of Manokwari, West Papua, Indonesia. Hayati J Biosci 25: 6-10.

Fusco G, Minelli A. 2010. Phenotypic plasticity in development and evolution: facts and concepts. Philos Trans R Soc Lond B Biol Sci 365: 547-556.

Geller J, Meyer C, Parker M, Hawk H. 2013. Redesign of PCR primers for mitochondrial cytochrome $\mathrm{c}$ oxidase subunit $\mathrm{I}$ for marine invertebrates and application in all-taxa biotic surveys. Mol Ecol Resour 13: 851-861.

Goud J, Van der Bijl B, Creuwels J. 2020. Naturalis Biodiversity Center (NL)-Crustacea. Naturalis Biodiversity Center. Occurrence dataset DOI: $10.15468 /$ vjoltu accessed via GBIF.org on 2020-11-19. https://www.gbif.org/occurrence/2434524033

Hebert PD, Cywinska A, Ball SL, DeWaard JR. 2003a. Biological identifications through DNA barcodes. Proc R Soc Lon B 270: 313 321.

Hebert PD, Ratnasingham S, DeWaard JR. 2003b. Barcoding animal life: cytochrome c oxidase subunit 1 divergence among closely related species. Proc Biol Sci 270: S96-S99.

Hijiriah. 2015. Analisis hidrologi sungai Rongkong Kab. Bulukumba. Kokoh 16: 31-44. [Indonesian]

Imron I, Sunandar D, Susilowati R, Suprapto R, Khasani I. 2009 Randomly amplified polymorphic DNA (RAPD) fingerprinting of six Indonesian populations of giant freshwater prawn, Macrobrachium rosenbergii. Indon Aquacult J 4: 93-100.

Jayachandran KV, Sebastian A. 2010. Morphometric and meristic studies of the spotted estuarine prawn, Macrobrachium Equidens (Dana) of Vembanad Lake, Kerala State. J Indian Fish Assoc 37: 1-6.

Jurniati, Arfiati D, Maizar A, Kurniawan A. 2020. Length-weight relationships and condition factor of sweet river prawn, Macrobrachium esculentum (Thalwitss, 1891) in the downstream Rongkong watershed. IOP Conf Ser Earth Environ Sci 441: 012093 DOI:10.1088/1755-1315/441/1/012093

Kaka RM, Jung'a JO, Badamana M, Ruwa RK, Karisa HC. 2019 Morphometric length-weight relationships of wild penaeid shrimps in Malindi-Ungwana Bay: Implications to aquaculture development in Kenya. Egypt J Aquat Res 45: 167-173.

Kounthongbang A, Lasasimma O, Souliyamath P, Iguchi K, Ito S. 2015 Life history characteristics of the fluvial shrimp Macrobrachium yu (Holthuis, 1950) (Decapoda, Palaemonidae) spawning in the cave streams in Northern Laos. Crustaceana 88: 164-183.

Kuguru B, Groeneveld J, Singh S, Mchomvu B. 2019. First record of giant freshwater prawn Macrobrachium rosenbergii (de Man, 1879) from small-scale fisheries in East Africa, confirmed with DNA barcoding. BioInvasions Rec 8: 379-391.

Kumar K, Rana AR, Kotnala CB. 2018. Taxonomic study and identification character of freshwater prawn Macrobrachium assamense peninsulare (Tiwari, 1958) in Garhwal region of Central Himalaya, India. Intl J Res Anal Rev 5: 485-491.

Kumar S, Stecher G, Tamura K. 2016. MEGA7: molecular evolutionary genetics analysis version 7.0 for bigger datasets. Mol Biol Evol 33: 1870-1874

Laewa NH, Fahri, Annawaty. 2018. The Freshwater Prawn Macrobrachium latidactylus (Decapoda, Caridea, Palaemonidae) from Gililana River, Morowali Utara, Sulawesi, Indonesia. Nat Sci J Sci Tech 7: 205-216.
Makombu JG, Stomeo F, Oben PM, et al. 2019. Morphological and molecular characterization of freshwater prawn of genus Macrobrachium in the coastal area of Cameroon. Ecol Evol 9: 1421714233.

Mar W, Kang EF, Mao B, Wang YF. 2018. Morphological and molecular features of some freshwater prawn species under genus Macrobrachium Spence Bate, 1868 (Crustacea: Decapoda: Palaemonidae) from Myanmar. Zootaxa 388: 123-132.

Michaux B. 2010. Biogeology of Wallacea: geotectonic models, areas of endemism, and natural biogeographical units. Biol J Linn Soc 101: 193-212.

Munasinghe DHN, Thushari GGN. 2010. Analysis of morphological variation of four populations of Macrobrachium rosenbergii (De Man, 1879) (Crustacea: Decapoda) in Sri Lanka. Ceylon J Sci 39: 53-60.

Muthmainnah D, Dahlan Z, Susanto RH, Gaffar AK, Priadi DP. 2016 Utilization of freshwater fish biodiversity as income source of poor rural people (Case study in Pampangan subdistrict of South Sumatra province, Indonesia). In: Nakano S, Yahara T, Nakashizuka T (eds.) Aquatic Biodiversity Conservation and Ecosystem Services. Springer, Singapore.

Nugroho E, Mulyasari M, Kristanto AH, Ali F, Gunawan G. 2009. Evaluation of genetic variability of freshwater prawn collected from Makassar-Sulawesi, Pangkalan Bun-Kalimantan, JambiSumatra,Sukabumi-Java, and GIMacro Using mtDNA CO-I Markers. Indone Aquacult J 3: 23-28.

Olivier TJ, Bauer RT. 2011. Female Downstream-Hatching Migration of the River Shrimp Macrobrachium ohione in the Lower Mississippi River and the Atchafalaya River. Am Midl Nat 166: 379-393.

Omobepade BP, Ajibare AO. 2015. Morpho-Fecundity of Berried African River Prawn (Macrobrachium vollenhovenii) in Asejire Reservoir, Nigeria. Intl J Fish Aquat Stud 3: 206-211.

Pileggi LG, Mantelatto FL. 2010. Molecular phylogeny of the freshwater prawn genus Macrobrachium (Decapoda, Palaemonidae), with emphasis on the relationships among selected American species. Invertebr Syst 24: 194-208.

Roskov Y, Kunze T, Orrell TM, et al. 2014. Species 2000 \& ITIS Catalogue of Life, 2014 Annual Checklist. Species 2000, Naturalis, Leiden, Netherlands.

Senckenberg. 2004. Collection Crustacea-ZMB. Occurrence dataset DOI: 10.15468/fwghff accessed via GBIF.org on 2020-11-19. https://www.gbif.org/occurrence/251627986

Sharma C, Krishna G, Kumar AP, Nayak S. 2014. Phylogeny of Macrobrachium species using mitochondrial 16S ribosomal DNA. J Cell Tiss Res 14: 4525-4529.

Short JW. 2004. A revision of Australian river prawns, Macrobrachium (Crustacea: Decapoda: Palaemonidae). Hydrobiologia 525:1-100.

Stelbrink B, Albrecht C, Hall R, Von Rintelen T. 2012. The biogeography of Sulawesi revisited: is there evidence for a vicariant origin of taxa on Wallace's "anomalous island"?. Evolution 66: 2252-2271.

Subbaiya R, Narasimman S, Lawanya R, Mahavinod AJKV, Masilamani SM. 2017. Studies on proximal composition and DNA barcoding of marine shrimps from Thondi, Tamilnadu, India. Intl Res J Pharm 8: 59-62.

The International Barcode of Life Consortium. 2016. International Barcode of Life project (iBOL). Occurrence dataset DOI: 10.15468/inygc6 accessed via GBIF.org on 2020-11-19. https://www.gbif.org/occurrence/2249508430

Thompson SK. 2012. Simple Random Sampling. In: Shewhart WA, Wilks SS (eds.) Sampling. $3^{\text {rd }}$ ed. John Wiley \& Sons, Inc, New Jersey.

Udayasuriyan R, Saravana Bhavan P, Vadivalagan C, Rajkumar G. 2015. Efficiency of different COI markers in DNA barcoding of freshwater prawn species. J Entomol Zool Stud 3: 98-110.

Utomo AD. 2017. Growth and biological reproduction of giant prawn (Macrobrachlum rosenbergii) at Lempuing River South Sumatra. Jurnal Penelitian Perikanan Indonesia 8: 15-26.

Ventura T, Nguyen C, Fitzgibbon QP, Abramov T, Smith GG, Elizur A. 2019. Crustacean larval factor shares structural characteristics with the insect-specific follicle cell protein. Sci Rep 9: 2847. DOI: 10.1038/s41598-019-39173-7

Wahidah, Omar SBA, Trijuno DD, Nugroho E. 2015. Morphometric variance of South Sulawesi's freshwater prawn Macrobrachium rosenbergii and Macrobrachium idae. Intl J Sci Res Pub 5: 1-5.

Wahidah, Andy Omar SBA, Trijuno DD, Nugroho E, Amrullah. 2017. The morphological characteristics of South Sulawesi's giant 
freshwater prawn Macrobrachium rosenbergii. AACL Bioflux 10: 820-829.

Wowor D, Choy SC. 2001. The Freshwater Prawns of the Genus Macrobrachium Bate, 1868 (Crustacea: Decapoda: Palaemonidae) from Brunei Darussalam. Raffles Bull Zool 49:269-289.

Wowor D, Cai Y, Ng PKL. 2004. Crustacea: Decapoda, Caridea. In: Yule, C.M. \& Yong, H.S. (Eds) Freshwater Invertebrates of the Malaysian Region. Academy of Sciences Malaysia, Kuala Lumpur.

Wowor D, Ng PKL. 2007. The giant freshwater prawns of the Macrobrachium rosenbergii species group (Crustacea: Decapoda: Caridea: Palaemonidae). Raffles Bull Zool 55: 321-336.
Wowor D, Muthu V, Meier R, Balke M, Cai Y, Ng PKL. 2009. Evolution of life history traits in Asian freshwater prawns of the genus Macrobrachium (Crustacea: Decapoda: Palaemonidae) based on multilocus molecular phylogenetic analysis. Mol Phylogenet Evol 52: 340-350.

Yatsuya M, Ueno M, Yamashita Y. 2012. Occurrence and distribution of freshwater shrimp in the Isazu and Yura Rivers, Kyoto, Western Japan. Plankton Benthos Res 7: 175-187. 